\title{
The Contributions of Private Strawberry Breeders
}

\author{
Harold A. Johnson, Jr. \\ Driscoll Strawberry Associates, Inc., Watsonville, CA 95076
}

\begin{abstract}
The grand qualities of our present-day strawberries are traceable to three native octoploid American types obtained from the east coast of North America (Fragaria virginiana Duch.), the west coast of South America ( $F$. chiloensis L.), and from the central California coast ( $F$. chiloensis). The cross of the first two, made about 1750, was the progenitor of the current short-day strawberry. The hybrid strawberry thus obtained was named pine, short for pineapple, and also the ananassa strawberry, which, of course, also means pineapple (Fig. 1A). The flavor resembles pineapple (Darrow, 1966; Wilhelm and Sagen, 1972). About 125 years later, the California strawberry germplasm was introduced, first into Belgium, then France and England, and used in crosses with germplasm derived from the original cross. Hybrids resulting were progenitors of the 'Perpetuel', that is, the everbearing class of strawberry (Wilhelm, 1974). What makes strawberries unique among fruit crops, and especially interesting to those of us involved in the commercial breeding of strawberries, is their octoploid ( $8 \mathrm{n})$ genetic composition, their recent interspecific (Fragaria spp.) hybrid origin, and the relatively short time between seed germination and fruiting. To meet present market standards, cultivars possess traits that have been pyramided, a term used by E. Goldsmith (Fig. 1E), over numerous seedling generations of selection and elimination. Worldwide, only a few private corporations are involved in strawberry breeding, but interest in private breeding ventures is growing. My own strawberry breeding efforts have been with Driscoll Strawberry Associates, Inc. (DSA), Watsonville, Calif. During the 34 years of my employment, upwards of 600,000 strawberry seedlings of hybrid origin have been raised, increased by runners, and fruited in blocks, often with replications in more than one location. The effort has resulted in 41 patented cultivars with unique qualities determined by DSA business policies. This work, all accomplished within a narrow parent base, has been recently turned over to T.M. Sjulin, formerly of Washington State Univ.
\end{abstract}

\section{ENVIRONMENTAL CONDITIONING GUIDED EARLY STRAWBERRY IMPROVEMENT}

Before the present era of employing cross breeding to achieve new plant types, horticulturists for centuries employed many cultural innovations to control or modify vegetative plant growth and fruiting cycles. With older strawberry types derived solely from $F$. vesca and $F$. virginiana, early and late season (including Christmas

\footnotetext{
I thank Stephen Wilhelm for offering me the use of his extensive library on strawberry history. Since preparation of this text, I have been informed that the following companies are involved in strawberry breeding.

Planasa

31514 Valtierra

Navarra, Spain

Consorizo Italiano Vivaisti

Via Giordano Bruno. 9

44039 Tresigallo (Ferrara), Italy

BHN Research

16750 Bonita Beach Road

Bonita Springs, FL 33923-0222

Western Operation:

2.52 San Andreas Road

Watsonville, CA 95076

Plant Sciences Inc.

514 Calabasas Road

Watsonville, CA 95076

If I have overlooked any companies, I apologize.
}

fruit production); large, attractive fruit; and control of runner production were achieved through cultural measures. With our present types, environmentally controlled conditioning still plays a large part in determining the onset and duration of vegetative and fruiting cycles. The Pacific Rural Press of 1909, for instance, records key early observations on such conditioning by a California grower: "From 1000 plants of Banner (Marshall) grown in a nursery in Northern California and planted in 1904 in Watsonville, 9000 runner plants were produced; in 1905 these 9000 plants produced only 125 runners, and next year the 125 plants produced no runners." Whereas some plant authorities, apprised of the situation, questioned the validity of the observations, A. Etter (Fig. 1D), selfmade strawberry breeder of California's northern woods, gave a short diagnosis: "Watsonville winters were too mild to alter the 'vegetative temperament' of this Eastern type plant." At present, all of DSA, and much of other California strawberry plant production, is in northern California nurseries, where the "vegetative temperament" induced by long, hot days of summer assures dependable and prolific runner production. Conversely, the short, cool days of Watsonville summers induce a vegetative temperament favorable to flowering and fruit production. It is imperative that successful strawberry breeders, especially in California, understand the environmental influence on seedlings and selections if they are going to maximize the genetic material available to them.

\section{INHERITED TRAITS GUIDE CULTIVAR SELECTION}

Though rewarding, and still central to achieving optimal plant and fruit production, the range of useful, environmentally conditioned changes in strawberry growth and fruiting patterns paled in importance to the range of latent variability observed in seedlings. This variability, when first appreciated, was simply attributed to unexplained chance and largely ignored. Later, when growers began to make crosses, variability realized in seedlings became an asset and enabled growers to choose parents with the idea of obtaining certain results. In strawberry seedlings, more so than among seedlings of other fruit, the new seedling traits were permanent under all conditions of the environment and were retained by all vegetative generations derived from the new seedling, and by all individuals of every new vegetative generation. Thus, in contrast to the reliance on plant conditioning techniques to induce the appearance of a trait, the new traits appearing in seedlings were expressed without any prior manipulation of the environment.

I believe that the first new trait recorded in a seedling of the present garden strawberry was red internal flesh color of the berry. The red flesh contrasted sharply to white or pale flesh of the original garden strawberry, which undoubtedly was its seed parent. Duchesne (1822) (Fig. 1B), first strawberry historian, named the new seedling Fragaria tincta, but it had been known long before by various names such as 'Strawberry of Haarlem', 'Strawberry of Canterbury', and others. I believe that both it and its progenitor, the original garden or pine strawberry, originated in Holland.

\section{CONTAGION OF STRAWBERRY BREEDING, ABETTED BY RED BERRY FLESH}

Thus, the new class of garden strawberry, which is our strawberry of commerce, offered exciting expectations for giving new types when grown from seed. Expectations far exceeded anything ever experienced during centuries of previous strawberry cultivation, in spite of the numerous innovations of culture employed by gardeners. Strawberry growers, gardeners, nurserymen, doctors, and business people took up strawberry breeding as a specialty or hobby. They shared alike in the excitement of making crosses and in discovering 

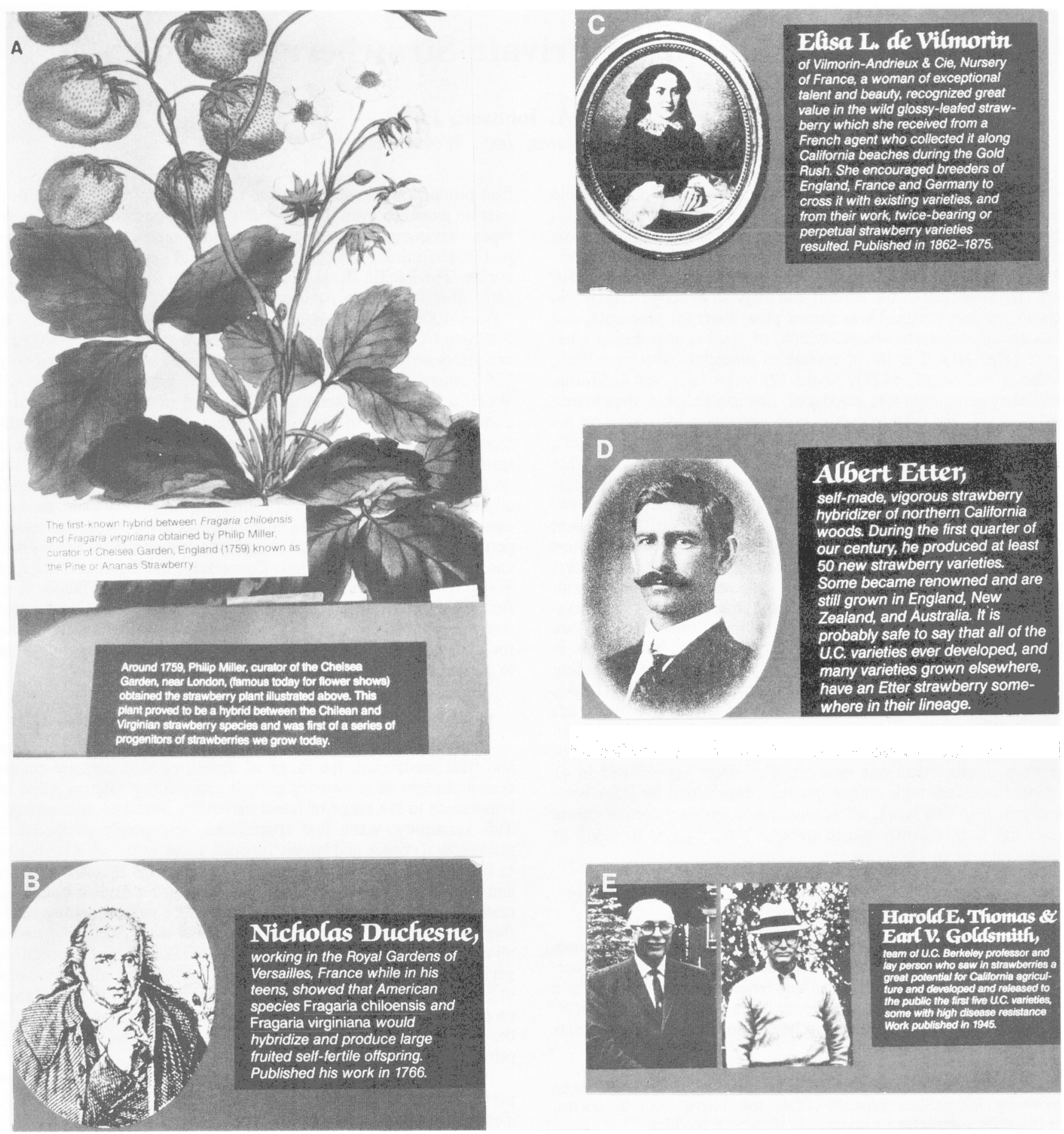

Fig. 1. Part of a display of the Santa Cruz County California Fair, Sept. 1988, featuring the history of our present strawberry. (A) Original pine or ananassa strawberry. (B) Nicholas Duchesne, first to prove hybrid origin of our strawberry. (C) Elisa L. de Vilmorin encouraged development of new strawberry types by cross breeding. (D) Albert Etter, California, legend dedicated to strawberry breeding. (E) Harold E. Thomas and Earl Goldsmith, professor and layman team, formulated principles of strawberry breeding and growing to achieve excellence in fruit quality, and to preserve the health of planting stock.

new types. Some raised hundreds, perhaps thousands, of seedlings, fruited them, and named and sold the best. Others settled for simply observing fruit produced by chance garden seedlings, many of which were also named and made available to the trade. Above all, the lives of these lay people were enriched by the excitement of discovery, by communication of their common interests, sometimes for days on end, at informal local horticultural society meetings, and by laying claim to a new plant creation they could identify by name, exhibit in public, and consider their own. These private breeders laid the foundation for the strawberries of unsurpassed excellence that we grow today.

The 19th century was a beehive of activity in strawberry breed- ing. In England, for instance, Michael Keens, strawberry grower of Isleworth, in 1806, selected 'Keens' Imperial', which appeared in a large population of seedlings of 'White Carolina' (Keens said 'White Chile'). In 1819, he selected 'Keens' Seedling', a creation of exceptional merit derived simply from seedlings of the 'Keens' Imperial'. 'Keens' Seedling' was a parent of 'Hovey', an early U.S. cultivar produced around 1840 by C.M. Hovey of Massachusetts. Berry flesh of both 'Keens' Seedling' and 'Hovey' was deep red, and 'Hovey', when aided by pollinators, produced great crops of eye-catching berries. 'Hovey' significantly affected the early American strawberry industry, and was brought to California about 1850 by a Dr. Broaddus of San Francisco. 

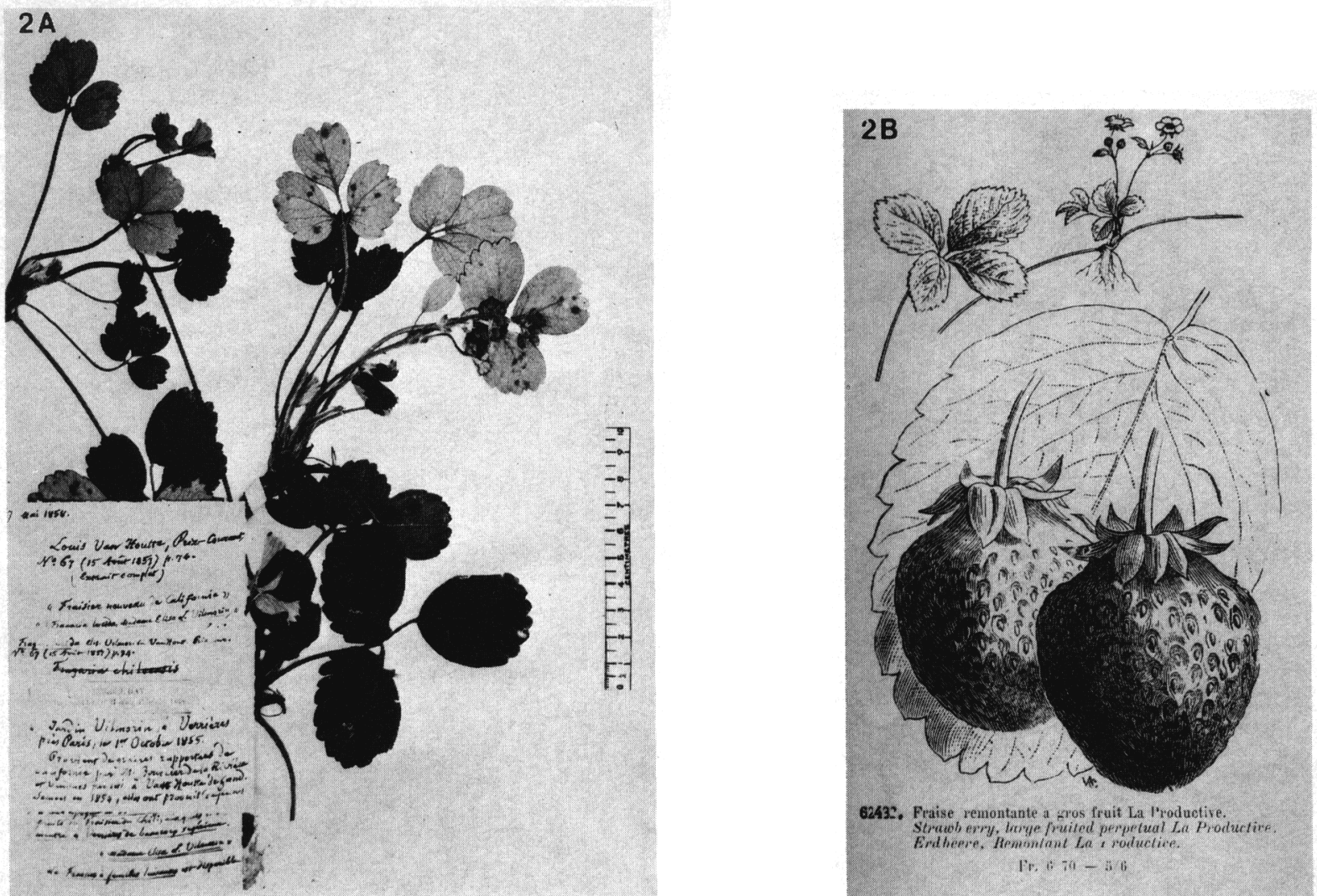

Fig. 2. (A) Specimen of Fragaria lucida (chiloensis) in Kew Herbarium, the label notes read: 17 May 1858 received specimens from Louis Van Houtte, as No. 67, 15 August 1857 P74. New strawberry from California, Fragaria lucida Madame Elisa L Vilmorin. Fragaria chiloensis Garden of Vilmorin, Verriers, Paris, 1 Oct. 1855. Brought from California by Boursier de la Riviere 1854. Seed purchased by Van Houtte of Ghent. (Many crosses were made using the 'Californian' seedlings as a seed parent.) (B) Illustration of the everbearing (remontant) character, namely fruiting on runners, of the cultivar 'La Productive' (from Vilmorin-Andrieux \& Cie. Album de Cliches, Paris, 3rd ed. 1911).

On the heels of Keens, Thomas Andrew Knight, President of the Horticultural Society of London, released 'Elton', syn. 'Downton', a cultivar with dark red flesh; it was valued in England for more than 100 years. Parents are unknown. The dark red flesh of these early cultivars suggests a connection to the 'Strawberry of Canterbury'.

A Mr. Myatt of Dextford, England, between 1840 and 1850, released 'British Queen', 'Eleanor', and 'Myatt's Eliza'. 'Eleanor' was popular because of deep red flesh. Parents are not known. 'Black Prince', described as having deeply colored flesh, was raised by a Mr. Cuthill of Camberwell around 1837. Shortly thereafter, John Salter, of Hammersmith, released 'Jacunda', which proved to be a long-lived, dependable cropper in England, the United States, and the Netherlands. Of cultivars developed during the first half of the 19th century, of which the above are but a small sampling, only 'Jacunda' is still available in the National Clonal Germplasm Repository at Corvallis, Ore. In the Netherlands, 'Jacunda', though white-fleshed, has been used in breeding until recently because of strong resistance to the common Ramularia leafspot fungus. Thus, in strawberry breeding, disease resistance, at times, must take preference over beauty. Also, the century long life of these early cultivars suggests a measure of freedom from virus disease.

During the latter part of the 19th century, new cultivars were raised primarily from crosses. 'Royal Sovereign' ('Noble' $x$ 'King of the Earlies') was produced in 1891 by Thomas Laxton, of the world-famous Laxton Brothers of Bedford. A vigorous, productive plant of bright-red fruit, 'Royal Sovereign' was grown until recently in England, British Columbia, and Nova Scotia. It is both grandfather and grandmother of 'Shasta', developed by Harold Thomas and Goldsmith (Fig. 1E) of Univ. of California, Berkeley, and released to the public in 1945. Over his life, Laxton produced $>20$ strawberry cultivars by hybridization. His accomplishments in strawberry breeding are recorded in a commemorative volume, written by the brothers William and Edward Laxton (1899).

\section{SYNTHESIS OF FIRST EVERBEARERS}

In France, at this time, strawberry culture flourished, due largely, I believe, to the devotion, scientific interest, and generosity of Elisa L. de Vilmorin (Fig. 1C) of Vilmorin - Andrieux et Cie of Verrières. In her large experimental garden, she raised strawberries of all types and cultivars, and also illustrated many of them in vol. 9 of Decaisne's "Le Jardin Fruitier du Museum" entitled "Le fraisier". She also described as a new species, Fragaria lucida, recently introduced from California. This $F$. lucida, later shown to be $F$. chiloensis was unique among all other of her strawberries because of its extremely shiny leaves, for which it was named, and its exceptional hardiness. Ferdinand Gloede (18.58) of Le Sablons, strawberry merchant and breeder, reported that the 'Californian', as it was known in the trade, was bifere, i.e., bore two crops in one year. A similar report was published by Theodor von Spreckelsen (1858) of Hamburg. Gloede, in 1866, was first to release a 'Californian' hybrid that he named 'Ananas Perpetuel'. This, I believe, is the first report of an everbearer in the octoploid garden strawberry. Fruit production on runners was the unique feature of everbearer (Fig. 2B). 'Ananas Perpetuel' did not live up to advertised expectations of fruit shape, quality, or quantity, especially in the United States, but one of its seedlings, named around 1871 'The Inexhaustible' (trans.) bore large excellent fruit without interruption from May to October. All in all, Gloede introduced an estimated 25 strawberry cultivars and published about as many papers in horticultural journals. His son, William Gloede, continued the business in Hamburg and Saint Lucien-les-Beauvais. Everbearers continued to be a significant part of French strawberry breeding. The horticulturist P. Trioreau, in his Les Fraisiers (1961), listed 16 everbearing cultivars that, by their names, suggest French origin. Thus, in my opinion, the great 19th century contribution of France was the introduction of genes for the everbearing habit, together with strong, glossy, disease-resistant leaves, into the 'Pine' class of 


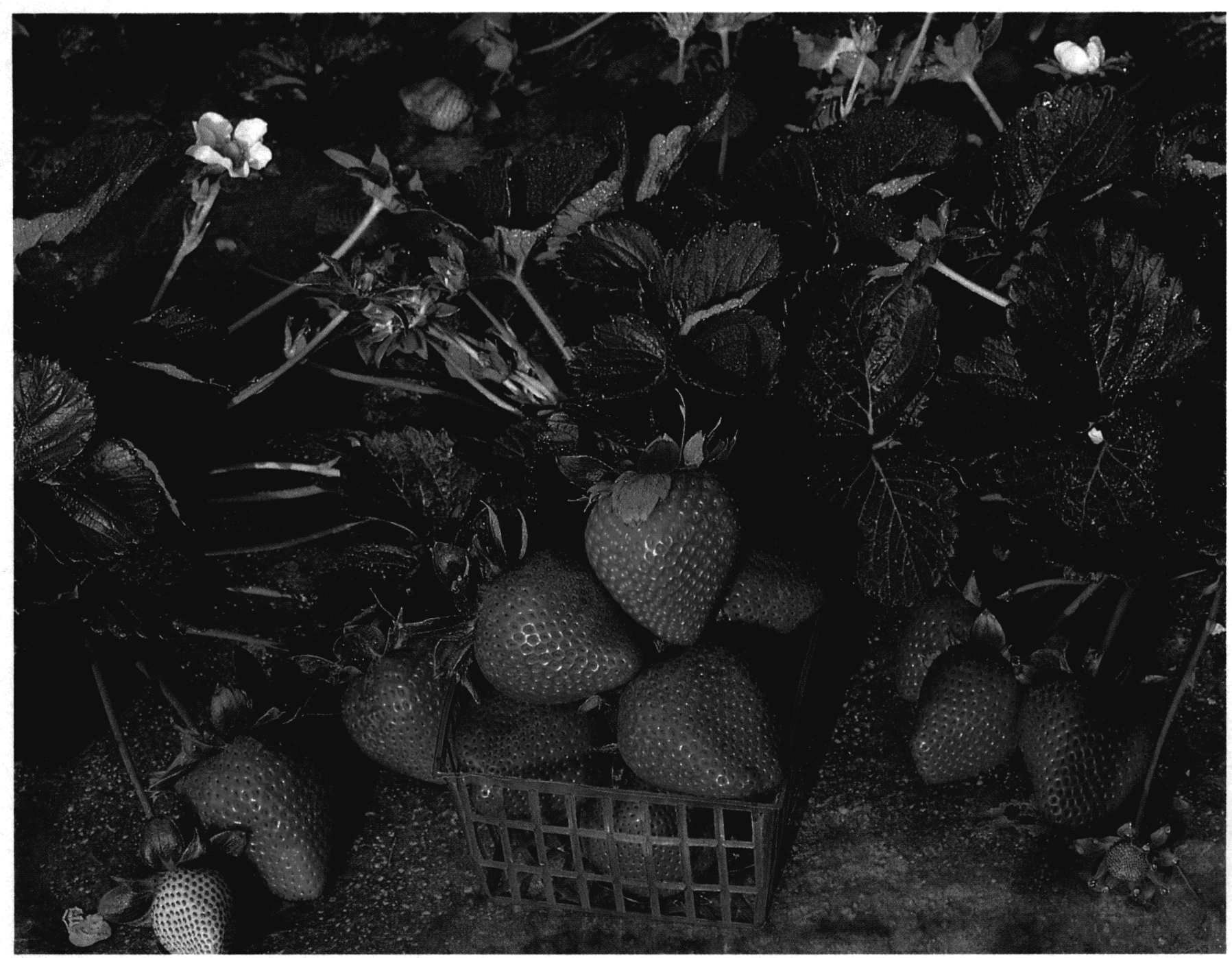

Fig. 3. 'Joe Reiter'-one of five patented cultivars grown in 1989 by Driscoll Strawberry Associates, Inc.

strawberry. Boursier de la Rivitre, French consular agent to California around 1850, collected seed of the original 'Californian' strawberry, probably from the vicinity of San Francisco (Fig. 2A), and sold them to Louis Van Houtte of Ghent, Belgium (Von Spreckelsen, 1858). There has been no strong strawberry breeding in France in this century, but now there appear to be three programs, one by the government, with Pierre Roudeillac in charge, and two private programs, one by the Darbonne family and another by Jacques Marionnet.

Belgium and Germany also made significant contributions to strawberry improvement. 'Triomphe de Gand', developed by M. de Jonghe of Brussels, provided large, sweet, fragrant fruit and was a significant cultivar in the early U.S. industry, where it was introduced around 1855. It was still listed in the catalog of Ellwanger and Barry, Rochester, N.Y., in 1880.

In Germany, the significant work on strawberries was done by Franz Goeschke, but he was head of a Pomological Institute in Proskau, and not a layman. He should be better known for his information-packed work: Das Buch der Erdbeeren (1888). Franz Goeschke and his father developed $>25$ hybrid strawberry cultivars. Today, Reinholt Hummel, in Weilimdorf, near Stuttgart, develops primarily strawberry cultivars for the home garden. His research facilities, greenhouses, and growing grounds are models of excellence in horticulture. His cultivars, all of which carry the prefix Hummi, are outstanding for beauty, flavor, and disease (mildew) resistance. Some of his best cultivars are Hummi-Ferma, Hummi-Grande, Hummi-Gento, and Klettererdbeere Hummi.

\section{U.S. EARLY CONTRIBUTIONS TO STRAWBERRY IMPROVEMENT}

Coming now closer to our time, Scott (1962) singled out three 19th century strawberry specialists whose contributions greatly influenced the direction and tempo of strawberry improvement in the United States. These were Nicholas Longworth of Cincinnati, known around 1845 for studies on dioecism of strawberry flower types, C.M. Hovey of Massachusetts, already mentioned for developing the 'Hovey' before 1840, and James Wilson of New York, who developed 'Wilson's Albany' around 1852. 'Wilson's Albany' was a self-fertile dependable bearer of firm fruit wherever in the United States it was grown. It was a prominent cultivar in the vicinity of San Francisco and in other coastal regions of California for half a century. The early activity in strawberry breeding in the United States is demonstrated by 1680 cultivars described by Hedrick (1925) in the impressive work "The Small Fruits of New York". Most of the cultivars had originated in North America, but had an English or European pedigree, and most were selected by private breeders spread over the United States from east to west, north to south. The best of the cultivars available to breeders between 1920 and 1930 included 'Howard 17' (Premier), 'Fendalcino', 'Ettersburg' 121 and 80, 'Banner' (Marshall), 'Nick Ohmer', '20th Century' (Bulach), 'Pan American', and 'Rockhill'. The last three are everbearers. It is interesting that the gene pool of these old cultivars did not display any of the fruit appearance characters required today in market strawberries, such as firmness, symmetry, smoothness, or high gloss. 
Yet, for the most part, pedigrees of all Driscoll cultivars (Fig. 3) are derivable from the above-named old cultivars.

Much has been written about the contribution of Albert Etter, strawberry breeder of northern California. Between 1903 and 1920, he released 50 outstanding cultivars. As strawberry parents he used $F$. chiloensis collected from beaches of Cape Mendocino near his home in Humbolt County, and South American collections made by the sea captain of a vessel plying the South American coast. Wilhelm and Sagen (1972) and Darrow (1966) have documented the value of Etter's creations. Etter's cultivars are represented in the genealogies of DSA and Univ. of California strawberry cultivars. As in any plant breeding activity, whether public or private, goals, plus a determination to fulfill the goals, play the major role in the success of the program.

\section{DRISCOLL STRAWBERRY ASSOCIATES, INC.,} PROGRAM

At this point, I would like to digress a little and discuss my own strawberry breeding program at DSA, together with factors that influenced the breeding goals and ultimately shaped DSA strawberry growing policies. It began as a story of two men, both experienced in strawberries, Harold E. Thomas, Plant Pathologist, Univ. of California, Berkeley, and E.F. (Ned) Driscoll, strawberry grower. Thomas, from long experience with strawberry diseases, set nursery and fruit production goals designed to minimize disease losses, and Ned Driscoll supplied the land, labor, and the day-byday hands-on drive to make this new breeding program successful. Outside funding for such Univ. of California projects did not exist. Kay Mukai, a Driscoll employee, soon was given charge of the evaluation of basic and advanced selections. He, "who essentially lived strawberries" first noted the outstanding traits of Cal. 403.8 and Cal. 544.2 in 1937 on a Driscoll-operated ranch in San Benito County, California. These selections, released to the trade as 'Shasta' and 'Lassen' in 1945, proved their worth in gold. In addition, they provided the impetus for development of strawberry cultivars unique to California. Driscoll Strawberry Associates have endowed the Kay Mukai Strawberry Research Foundation in his honor.

Obstacles, primarily in the form of imperfectly understood diseases that plagued the California industry between 1920 to 1945 , have largely shaped Driscoll's broad growing policies. The first disease was "yellows", described by Plakidas (1926, 1927) of Univ. of California, Berkeley. This disease so impressed Thomas and Driscoll with its destructiveness, even though it was not always visible in plants, that to this day it dictates the direction of breeding and policies of strawberry nursery location and management. For example, in the early 1930s, 'Nick Ohmer', which originated in Ohio around-1898, had nearly replaced 'Banner'. 'Banner' was very susceptible to yellows, and was being maintained exclusively in California nurseries. Roguing was the accepted practice for maintaining healthy stock. In 1930, Driscoll planted 16.2 ha of 'Nick Ohmer' in a ranch near Aptos called the Polo Field, from plants derived from a nursery in which Thomas believed that roguing had eliminated most of the plants showing obvious virus symptoms. The stock proved to be good, and a production of 4000 crates per acre (24 US tons; 1620 crates/ha; 22 t) of marketed berries was achieved. The next year, wanting to economize and assuming that plants were healthy, Driscoll planted a new ranch, called Seacliff, with 'Nick Ohmer' runners saved from the Polo Field. The result was a total loss due to virus diseases. In fact, production was so poor that he lost all of the profits made previously on the Polo Field ranch. This disaster, as it was called, in the end had a positive side. Strawberry growers became alerted to the fact of virus diseases, though. etiologies were unknown, to the need to isolate nurseries geographically from fruiting fields, and to the superiority of northern California-grown stock. It also became obvious that visual observations were not good enough to decide the virus status of plants. This pinpointed the need for a method of detecting strawberry viruses, particularly because the Polo Field experience showed they could remain latent in the plants for months without causing obvious symptoms. Fortunately, Harris, of England, had developed a detection method using stolon grafting that transmitted the viruses to susceptible indicators. Norman Frazier picked up on this technique in 1939 and ended up making strawberry viruses and virus detection his life's work. He developed highly susceptible and selective strawberry indicators from among $F$. vesca and $F$. virginiana types. These indicators were, and to this day still are, widely used by the California Dept. of Food and Agriculture, Nursery Services, the Univ. of California strawberry breeding program, and by DSA. There were no other reliable methods of detecting the presence of strawberry viruses in foundation nursery stocks.

The Polo Field experience was decisive. Thomas became convinced that California strawberry growers must have their own cultivars and have control of their own nurseries and of any other propagation facilities. Because viruses at the time were, for the most part, invisible mysterious entities, plants from out of the state, even though appearing to be healthy, could not be trusted to be virusfree. As a result, Thomas, still a Univ. of California plant pathologist, with an assistant, Earl Goldsmith, picked up the pieces of an infant breeding program devoted largely to searching for virus disease resistance. In 1945, they were able to release the famous five Univ. of California strawberry cultivars. Of these, 'Lassen' possessed an unusual adaptability to environmental conditions and has been a major contributor in the UC cultivars developed since 1945 . The commercial fields of Ned Driscoll were available to Thomas and Goldsmith for strawberry seedling evaluations. In 1944, the Strawberry Institute of California was formed, with Thomas as director and Goldsmith as strawberry breeder. In 1965, the Strawberry Institute of California merged with Driscoll Strawberry Associates.

\section{INPUT FROM GROWERS AND SHIPPERS IS VALUABLE}

It has been helpful to grow new strawberry selections on growers' ranches and observe them under specific grower management and cultural practices. Also valuable has been input from quality control inspectors and, above all, opinions from buyers as far away as the East Coast, 4 days by truck. Comments of local shoppers have always been sought. Any breeder can make observations, but the confirmation of a marketing group and their contacts is the final stamp of approval. Appearance and flavor at the marketplace are the key issues. Driscoll Strawberry Associates places great emphasis on fruit size, holding ability during transit, gloss, shape, color, skin and flesh firmness, and appearance and flavor at the store level from early spring to late fall. These traits are constantly evaluated. Nor has DSA forgotten the criticism of 'Goldsmith', their main cultivar during the 1960s, for poor flavor.

\section{BREEDING GOALS}

Beginning with the 1950s, and continuing to the present, DSA breeding goals have been no different from those familiar to strawberry breeders everywhere. I have listed ours in order of importance, as DSA views it.

1) Shelf life-Shelf life involves both skin and flesh firmness. Parents that transmit firmness without jeopardizing other characters are extremely valuable. The disease known as albinism complicates breeding for firm fruit and may obviate its expression. Albinism can cause weak skin and poor skin color. Fortunately, cultural practices that maximize the sugars available to the fruit help reduce albinism, but the breeder is wise to screen out parents and selections that are prone to express this condition.

2) Virus disease resistance-In earlier years, fields were kept in strawberries for several years, and the practice of evaluating new selections within, or near, old fields exposed new selections to severe virus pressure. The obviously susceptible selections were thus eliminated.

3) High pollen production-As the industry moved toward the coast from the Santa Clara and San Joaquin valleys, to cooler weather, lack of adequate pollination became a problem. Selection for good pollen production became imperative.

4) Resistance to transient June or Blakemore yellows-This problem hit in the early 1960s. It was unsettling because we knew it to be capable of destroying the present garden strawberry. The cause is still not very well-understood. We have found that parents transmit this condition in varying degrees, but we do not understand the inheritance. 
5) Resistance to Botrytis and Rhizopus fruit rots-These diseases continue to be serious problems and have been aggravated by our selection for the large attractive calyx. Fortunately, resistant parents have been identified and progress toward fruit rot resistance is being made. Fruit rot resistance is not linked with fruit firmness.

6) Ease of picking-One of the values of working directly with a fruit growing organization is that growers are not bashful about verbalizing their observations. From growers, we have learned that, during the fruiting season, a given cultivar may produce an inflorescence that does not allow pickers to pick and pack rapidly, and the final crate may not be an attractive pack. The density of the foliage, the type of foliage, and the availability and consistent size of the fruit is often more important than whether the plant is just small or large. The cost of picking a crate correlates with profit. This statement perhaps is redundant, but I know from experience that a breeder can underrate its high priority. In some cultivars, there is too great a size difference between primary, secondary, and tertiary berries and, in some cultivars, the primary, secondary, and tertiary fruit of summer and fall crops, in contrast to that of spring crops, drops off sharply in size. The lack of consistency in fruit size increases the cost of picking and contributes to poor appearance of the crate of berries.

7) Resistance to soil-borne diseases-Preplant soil fumigation of both fruiting fields and nurseries, primarily with mixtures of chloropicrin and methyl bromide, has enormously benefited the California strawberry industry. It removed the major uncertainty to achieving profitable yields and has permitted replanting on the same lands year after year for up to 3.5 years. Diseases still persist, however, and among those most pressing are root rots and fruit rots caused by the following fungal pathogens: Ceratobasidium ( Rhizoctonia ) fragariae, Colletotrichum acutatum, Phytophthora cactorum, and $P$. fragariae. Cultivars resistant to verticillium wilt would also be welcome. Resistance to all-of these pathogens is available, but at this point they all remain a threat, especially to the DSA germplasm. Should the availability of fumigation be lost, the above pathogens could again resume their harmful role.

8) Pest resistance-Injury from extreme susceptibility to the two spotted spider mite and thrips has eliminated selections through the years, and a degree of tolerance seems to be available at present. Fruit of DSA with a high gloss seems to be very susceptible to bronzing from thrips feeding.

9) Powdery mildew and leaf spot resistance-Both of these diseases have eliminated their share of selections. When we felt confident that we were achieving a fairly high level of resistance, we often were disappointed, especially with the mildew disease, of which there are probably many strains.

At the seedling level, we have put a higher priority on horticultural characters than on diseases or pest resistance. At the selection level, however, we are screening for resistance to as many of the above problems as possible. The commitment of the California strawberry industry to the biological control of pests is encouraging. Breeding goals will be influenced by this change. For instance, we have observed that cultivars that show phytotoxic injury to pesticides become more vegetative when under a biological control regime. This has benefited high-chilling cultivars when grown under conditions with less-than-ideal chilling.

\section{THE FUTURE}

Most strawberry growers in California depend on institutional research to help them solve problems. Growers of DSA realize a mutual value in aiding research outside their own organization. With this in mind, DSA has honored Kay Mukai by establishing a nonprofit research foundation in his name. Research in the future, if it is to be sustained, we believe must depend on funding made available through industry-supported foundations. The scientists receiving funds from the Kay Mukai Foundation are encouraged to make public the results.

A scientist from the state of Washington is screening $F$. chiloensis for disease and pest resistance. Another is attempting to identify genotypes in $F$. chiloensis with high photosynthetic rates and high water use efficiency. In Ontario, Canada, a researcher is screening 1200 distinct clones from the wild $F$. virginiana for superior genotypes. Work at the Univ. of Florida is attempting to discover cultivars resistant to Colletotrichum spp. and, at the Univ. of California, Berkeley, new control measures for this disease are being studied. Breeding stock from all this work will be available to public and private plant breeders. Work at Oregon State Univ. and British Columbia is directed at new methods of detecting strawberry mild yellow edge and mottle viruses. A bacteriologist at the Univ. of California, Berkeley, is studying various bacteria--as they affect strawberry health and cold sensitivity. Also, a weed control specialist at the Univ. of California, Davis, is evaluating soil solarization for control of fungal pathogens and weeds. A USDA scientist at Beltsville, Md., is studying flavonoid pigments of strawberries in relation to dormancy. A worker in Minnesota is attempting to identify the genetic diversity of volatile flavor components in wild and cultivated strawberries as a basis for improving fruit flavors. The above is a checklist of research areas that we believe will provide direction for strawberry breeding of the future, whether private or public. It is encouraging also that year-round market demand for strawberry fruit is increasing. The germplasm by which new cultivars can meet that demand is available, we believe, in the strawberry species. Its identification and ready availability, we trust, should provide incentives for strawberry breeders for many years to come.

\section{Literature Cited}

Darrow, G.M. 1966. The strawberry-history, breeding, and physiology. Holt, Rinehart, and Wilson, New York.

Duchesne, A.N. 1822 Fraisier. Nouvean cours complet d'agriculture . . . new ed. vol. 7. Deterville, Paris.

Gloede, F. 1858. Note sur le Fragaria lucida ou Fraisier de Californie. Flore des serres et der jardins de l'Europe 13:9-10.

Goeschke, F. 1888. Das Buch der Erdbeeren, Paul Parey, Berlin.

Hedrick, V.P. 1925. The small fruits of New York. J.B. Lyon, Albany, N.Y.

Laxton, W. and E. Laxton. 1899. The strawberry manual, an illustrated upto-date work on the strawberry. Hulatt and Richardson, Bedford, England.

Plakidas, A.G. 1926. Strawberry "yellows", a degeneration disease of the strawberry. Phytopathology 16:423-426.

Plakidas, A.G. 1927. Strawberry xanthosis (yellows), a new insect borne disease. J. Agr. Res. 35:1057-1090.

Scott, D.H. 1962. Breeding and improvement of the strawberry, in the United States of America - a review. Hort. Res. 2:35-55.

Trioreau, P. 1961. Les fraisiers. J.B. Bailliere et fils, Paris.

Von Sprkckelsen, T. 1858. Fragaria Lucida, die sogenannte Kalifornische Erdbeere. Hamburger Garten - und Blumenzeitung 14:390-393.

Wilhelm. S. and J.E. Saeen. 1972. A history of the strawberry from ancient gardens to modern markets. Agricultural Publications, Univ. of California, Berkeley.

Wilhelm, S. 1974. The garden strawberry: A study of its origin. Amer. Scientist 62:264-271. 